\title{
PENGARUH KEMAMPUAN MEMBUAT SIMULASI BERBASIS M-FILE TERHADAP KEMAMPUAN MEMBUAT SIMULASI GUI PADA PROGRAM MATLAB
}

\author{
Zainul Arifin, Muhammad Irwanti \\ Dosen Tetap IAI Hamzanwadi NW Lombok Timur \\ Email: azainul630@gmail.com
}

\begin{abstract}
Abstrak: Penelitian ini bertujuan untuk mengetahui adanya pengaruh kemampuan membuat simulasi berbasis M-file terhadap kemampuan membuat simulasi berbasis GUI (Grafical User Interface) Pada Program MATLAB di Program Studi Tadris Matematika Semester IV Tahun Pelajaran 2018/2019. Adapun analisis data, penelitian menggunakan analisis regresi linier sederhana dengan bantuan Software MINITAB untuk mengetahui ada atau tidaknya pengaruh antar variabel. Berdasarkan hasil analisis, diperoleh nilai $r_{\text {hitung }}=20.80$. Nilai ini selanjutnya dibandingkan dengan nilai rtabel dengan taraf signifikansi $5 \%$ dan diperoleh $r_{\text {tabel }}$ $=4,10$. Dari hal tersebut, diperoleh bahwa $r_{\text {hitung }}>r_{\text {tabel }}$. Hasil kemampuan simulasi $M$-file terdapat 10 orang mahasiswa yang kemampuan membuat simulasi M-file dalam katagori tinggi dengan presentase sebesar $27 \%, 27$ orang mahasiswa memiliki kemampuan berbasis M-file dalam kategori sedang dengan presentase $73 \%$ dan tidak ada memiliki kemampuan rendah. Kemampuan membuat simulasi berbasis GUI terdapat 8 orang mahasiswa memiliki Hasil kemampuan berbasis GUI dalam kategori tinggi dengan presentase sebesar $22 \%, 29$ orang mahasiswa memiliki Hasil kemampuan berbasis GUI dalam kategori sedang dengan presentase sebesar $78 \%$ dan tidak ada mahasiswa yang memiliki kemampuan berbasis GUI dalam kategori rendah. Sehingga dari hasil ini menunjukkan Ada Pengaruh Kemampuan Mahasiswa Membuat Simulasi Berbasis M-File Terhadap Kemampuan Membuat Simulasi Berbasis GUI Pada Program MATLAB.
\end{abstract}

Kata kunci: Simulasi Berbasis M-file, Simulasi Berbasis GUI (Grafical User Interface)

Abstract: This study aims to determine the effect of the ability to create simulations based on $M$ file on the ability to create simulations based on GUI (Graphical User Interface) in the MATLAB Program in the Tadris Mathematics Study Program Semester IV 2018/2019 Academic Year. For data analysis, the study used simple linear regression analysis with the help of MINITAB Software to determine whether or not there is an influence between the variables. Based on the results of the analysis, the value of $r_{\text {hitung }}=20.80$. This value was then compared with the $r$ table value with a significance level of $5 \%$ and the $r_{\text {tabel }}$ was obtained $=4.10$. From this, it is obtained $r_{\text {hitung }}>r_{\text {tabel }}$. The result of M-file simulation ability is 10 students whose ability to make M-file simulation is in the high category with a percentage of $27 \%, 27$ students have M-file-based ability in a medium category with a percentage of 73 $\%$ and none have the low ability. Ability to create GUI -based simulations, 8 students have GUI -based ability to produce high category with $22 \%$ percentage, 29 students have GUI based ability result in a medium category with $78 \%$ percentage and no students who have GUI -based skills in GUI -based category. low So from these results, shows that there is an influence of students' ability to create M-file-based simulations on the ability to create GUIbased simulations in MATLAB programs..

Keywords: M-file Based Simulation, GUI Based Simulation (Graphical User Interface) 


\section{PENDAHULUAN}

Era globalisasi yang ditandai dengan persaingan kualitas atau mutu, menuntut semua pihak dalam berbagai bidang dan sektor pembangunan untuk senantiasa meningkatkan kompetensinya. Hal tersebut mendudukkan pentingnya upaya peningkatan kualitas pendidikan baik kuantitas maupun kualitas yang seharusnya dilakukan terus menerus, sehingga pendidikan dapat digunakan sebagai wahana dalam membangun Sumber Daya Manusia berkualitas. Sesuai dengan sistem pendidikan nasional (UU RI No.20 Tahun 2003) yang dikutip dalam Ramayulis menyatakan bahwa pendidikan adalah usaha sadar dan terencana untuk mewujudkan suasana belajar dan proses pembelajaran agar peserta didik secara aktif mengembangkan potensi dirinya untuk memiliki kekuatan spiritual keagamaan, pengendalian diri, kepribadian, kecerdasan, akhlak mulia, serta keterampilan yang diperlukan dirinya, masyarakat bangsa dan Negara. (Ramayulis, 2011:13)

Beberapa ahli matematik menuntut simulasi harus digunakan hanya sebagai pendekatan. Sebagian mahasiswa berpendapat bahwa pembuatan simulasi tersebut dengan cara mengetik beberapa perintah langsung dari jendela Command Window, tapi mengetik di command window harus benar-benar paham baik dalam materi, simulasi, maupun bahasa pemogramannya, karena di dalam command window ketika menuliskan simulasi, kemudian terjadi kesalahan dalam penulisannya tidak bisa memperbaiki pada simulasi yang salah itu saja melankan harus mengulang membuatnya dari awal. Hal ini sering sekali yang dialami oleh mahasiswa yang menjadi faktor utama penyebab bosan jengkel dan tidak mau belajar sehinga berdampak pada nilai mahasiswa yang di dapatkan8, untuk menyikapi hal ini, untuk itu dalam program MATLAB terdapat M-file dan GUI (Grafical User Interface). Penelitian ini berawal dari permasalahan yang ada di kalangan mahasiswa yang mengikuti kuliah matematika komputasi. Matematika komputasi ini diaplikasikan dalam bentuk pembelajaran berbagai program komputer. Adapun program komputer tersebut terdiri dari program MATLAB,

Kesulitan pemrograman dari masing-masing program ternyata MATLAB merupakan program yang sifatnya sangat rumit sehingga membutuhkan ketelitian dalam membuat simulasi pemrogramannya. MATLAB merupakan suatu program komputer yang bisa membantu memecahkan berbagai masalah matematis yang kerap kita temui dalam bidang teknis. Kita bisa memanfaatkan kemampuan MATLAB untuk menemukan solusi dari berbagai masalah numerik secara cepat mulai hal yang paling dasar hingga yang kompleks. Aris sugiarto berpendapat bahwa MATLAB merupakan bahasa pemograman dengan kemampuan tinggi dalam bidang komputasi.(Sugiharto,2006:1)

MATLAB (Matrix Laboratory) adalah sebuah program untuk analisis dan computer numeric, merupakan suatu bahasa pemograman matematika lanjutan yang dibentuk dengan dasar pemikiran menggunakan sifat dan bentuk matriks.(Pusadan,2012:1)

Hasil observasi pada sebagian mahasiswa di dalam mempelajari MATLAB yang ada di lingkungan jurusan prodi tadris matematika yang sudah menempuh mata kuliah program komputer basic bahwa mahasiswa rata-rata mengalami masalah yang mendasar yaitu membuat simulasi. Dalam membuat simulasi sering sekali mahasiswa tidak memahami konsep dasar matematika yang mereka buat. Secara umum simulasi merupakan substitusi yang sesuai untuk pemecahan analitik dari suatu model situasi tertentu.(Richard dkk,2002:557)

M-file merupakan sederetan bahasa perintah matlab yang dituliskan secara berurutan sebagai sebuah file.(Sugiharto,2006:25) M-file dapat ditulis sebagai sebuah script yang sederhana atau dapat pula ditulis sebagai sebuah fungsi yang menerima argument atau masukan dan menghasilkan output, tidak lain tujuannya adalah untuk merangsang 
kemampuan peserta didik dalam bidang MATLAB dalam menyelesaikan materi-materi matematika.

GUI umumnya lebih mudah dipelajari dan digunakan karena orang yang menjalankannya tidak perlu mengetahui perintah yang ada dan bagaimana perintah bekerja. GUI merupakan sebuah graphical unser interface yang dibangun dengan obyek gerafis seperti tombol (button), kotak teks, slider, sumbu (axes), maupun menu.10 Dalam pembelajaran program MATLAB memang perlu pembuatan simulasi, baik itu pada M-file maupun simulasi pada GUI (Grafical User Interface) sehingga semua mahasiswa agar mereka tidak merasa bosan, jengkel atau takut dalam pelajaran tersebut.

Berdasarkan latar belakang di atas, maka penulis tertarik untuk meneliti tentang "Pengaruh Kemampuan Mahasiswa Membuat Simulasi Berbasis M-File Terhadap Kemampuan Membuat Simulasi Berbasis GUI (Grafical User Interface) Pada Program MATLAB di Program Studi Tadris Matematika Semester IV Tahun Pelajaran 2018/2019".

\section{METODE PENELITIAN Desain Dan Pendekaatan Penelitian}

Desain penelitian adalah jenis atau corak penelitian yang disebut juga dengan metode atau strategi penelitian. Corak penelitian ini sangat ditentukan oleh tujuan penelitian itu sendiri. Dilihat dari timbulnya variabel, penelitian ini merupakan penelitian Ex-post facto, dimana penelitian yang dilakukan atas peristiwa yang telah terjadi untuk menemukan pengaruh atau hubungan variabel tertentu dengan variabel lainnya, tanpa adanya manipulasi langsung terhadap variabel independen.(Arifin,2012:42-43) Karena penelitan ini bermaksud untuk menemukan pengaruh/ hubungan antara satu variabel bebas dengan satu variabel terikat yaitu simulasi M-file (variabel bebas) dengan simulasi GUI (Grafical User Interface) (variabel terikat).

Penelitan ini menggunakan pendekatan kuantitatif yaitu penelitian yang digunakan untuk menjawab permasalahan dengan pengukuran yang cermat terhadap variabel-variabel tertentu yang diproses secara statistic, sehingga menghasilkan kesimpulan yang dapat digeneralisasikan, lepas dari konteks waktu dan situasi.(Arifin,2012:29)

\section{Populasi dan Sampel}

Populasi adalah wilayah generalisasi yang terdiri atas objek atau subjek yang menjadi kualitas dan karakteristik tertentu yang ditetapkan oleh peneliti untuk dipelajari dan kemudian ditarik kesimpulannya.(Sugiyono,2014:117) Menurut Suharsimi (2002:104) apabila subjeknya kurang dari 100 maka lebih baik diambil semuanya, sehingga penelitiannya adalah penelitian populasi (populasi kurang dari 100 maka dipakai rumus $\mathrm{N}=\mathrm{n}$ yang artinya populasi adalah sampel) Selanjutnya jika subjeknya besar, dapat diambil diantara $10 \%-15 \%$ atau $20 \%-25 \%$ atau lebih. (Suharsimi,2006:134)

Berdasarkan pengertian tersebut, populasi sasaran penelitan ini adalah mahasiswa semester IV (empat) yang sedang menempuh mata kuliah PKB (program computer besic) terdiri dari kelas A, B, C, D dan E dengan jumlah (total) mahasiswa sebanyak 147 orang.

Sampel adalah bagian dari jumlah dan karakteristik yang dimiliki oleh populasi. Sejalan dengan permasalahan yang akan diteliti yaitu Kemampuan Mahasiswa Membuat Simulasi Berbasis M-File Terhadap Kemampuan Membuat Simulasi Berbasis GUI (Grafical User Interface) Pada Program Matlab, maka teknik pengambilan sampel yang digunakan dalam penelitian ini adalah Simple Random Sampling atau pengambilan sampel secara acak. Alasan peneliti mengambil Simple Random Sampling karena pengambilan sampel dari populasi dilakukan secara acak tanpa memperhatikan strata yang ada dalam populasi itu, sebab populasi dianggap homogen.(Sugiyono,2013:120) 
Pengambilan sampel dari populasi dilakukan secara acak tanpa memperhatikan strata yang ada dalam populasi itu, Maka peneliti mengelompokan penarikan sample dengan cara mengelompokan mahasiswa laki-laki dan mahasiswa perempuan sehingga dari kelas $A$ dapat mengambil sampel berjumlah 8 mahasiswa yaitu 3 laki-laki dan 5 perempuan sedangkan pada kelas B penarikan sample berjumlah 7 mahasiswa 2 laki-laki dan 5 perempuan pada kelas $C$ sample terambil 8 mahasiswa 3 laki-laki dan 5 perempuan dan kelas $D$ penarikan sample berjumlah 7 mahasiswa 2 laki-laki dan 5 perempuan sedangkan pada kelas $E$ penarikan sample tersebut berjumlah 7 mahasiswa 1 laki-laki dan 6 perempuan sehingga jumlah sampel berjumlah 37 orang mahasiswa.

\section{Teknik Analisa Data}

Upaya untuk memperoleh gambaran yang jelas mengenai data pada masing-masing variabel, serta untuk menguji hipotesis penelitian, terlebih dahulu dilakukan analisis data. Pada bagian ini akan dibahas berturut-turut mengenai:

1. Teknik Uji Persyaratan Analisis

Analisis dalam penelitian ini menggnakan analisis statistik parametric. Teknik analisis statistik parametrik membutuhkan uji normalitas data dan uji linieritas data. Pembuktian normalitas data dimaksud untuk mengetahui data yang akan dianalisis, apakah telah menghampiri data normal atau pengujian normalitas data dilakukan dengan menggunakan data dengan menggunakan chi kuadrat (X2). Kriteria pengujian normalitas data ini adalah : data berdistribusi normal jika $x 2$ hitung $<x 2$ tabel dan tidak berdistribusi nomal jika $\times 2$ hitung $>\times 2$ tabel

2. Teknik Uji Hipotesis

Teknik korelasi product moment merupakan salah satu teknik untuk mencari hubungan dua variabel bila data kedua variabel berbentuk interval atau rasio, dan sumber data dari dua variabel atau lebih tersebut adalah sama (sugiyono,2013:228). Penelitian ini menggunakan korelasi product momen sebagai teknik analisa data yang bertujuan untuk mengetahui korelasi M-file dengan GUI.

\section{HASIL PENELITIAN}

Hasil untuk mengukur kemampuan simulasi M-file dengan menggunakan MINITAB, diperoleh rata-rata skor dari penskoran soal tersebut adalah 76.60. Sedangkan pada data kemampuan simulasi GUI, diperoleh nilai rata-rata sebesar 75,36

Nilai koefisien korelasi yang diperoleh pada penelitian ini menurut hasil output olah data $\left(r_{\text {hitung }}\right)$ adalah 0,611 . Sedangkan nilai $r_{\text {tabel }}$ dengan $=0,05$ adalah 0,325 . Ini berarti $r_{\text {hitung }} \geq$ $r_{\text {tabel }}$ yang artinya terdapat hubungan antara kedua variabel tersebut.

Sedangkan pada perhitungan regresi linier bahwa $F_{\text {hitung }}>F_{\text {tabel }}$ atau $20.80>4,10$ maka hipotesis diterima. Peneliti menyimpulkan dalam penelitian ini bahwa "Ada Pengaruh Kemampuan Mahasiswa Membuat Simulasi Berbasis M-File Terhadap Kemampuan Membuat Simulasi Berbasis GUI (Grafical User Interface) Pada Program MATLAB di Program Studi Tadris Matematika Semester IV Tahun Pelajaran 2018/2019".

\section{PEMBAHASAN}

Penelitian ini menggunakan jenis penelitian ex post facto, dimana dalam memperoleh data peneliti hanya menyebarkan instrumen simulasi M-file sedangkan untuk simulasi GUI didapatkan dari dokumentasi. Sebelum di sebarkan instrumen terlebih dahulu divalidasi ahli, validitas instrumen untuk mengetahui tingkat akurasi dan menentukan tingkat kesukaran suatu instrumen supaya layak digunakan untuk mengukur apa yang ingin di ukur. Peneliti melakukan validasi dimana di dalam menguji validitas soal, peneliti membuat soal validasi 
sebanyak 10 butir soal. Berdasarkan analisis yang dilakukan dengan rumus Pearson Product Momen diperoleh bahwa ada 1 (satu) item yang tidak valid dan ada 9 (sembilan) item yang valid untuk instrumen simulasi M-file. Setelah di ketahui validitas, selanjutnya peneliti menyebarkan soal simulasi M-file kepada mahasiswa semester IV yang sedang menempuh mata kuliah program computer besic (PKB). soal ini dibuat sendiri oleh peneliti dengan melihat kerangka teori dan materi yang diajarkan pada mahasiswa, Setelah data terkumpul kemudian dianalisis.

Teknik sampling yang digunakan dalam penelitian ini adalah Simple Random Sampling atau pengambilan sampel secara acak tanpa memperhatikan strata yang ada dalam populasi dimana jumlah populasi dalam penelitian 147 orang sedangkan pengambilan sampel sebanyak 37 orang mahasiswa. Penelitian ini sampel tidak diberikan perlakuan apapun karena penelitian ini bersifat exspostfacto. Sampel hanya diberikan soal simulasi Mfile dan menjawabnya sesuai dengan kemampuan dari masing-masing mahasiswa.

Pengujian selanjutnya yang dilakukan adalah uji normalitas, hasil uji normalitas menunjukkan bahwa sampel tersebut terdistribusi normal. Selanjutnya dilakukan pengujian statistik dengan menggunakan statistik parametrik yaitu dengan uji regresi linier sederhana. Uji regresi untuk mengetahui ada atau tidak adanya pengaruh kemampuan simulasi $\mathrm{M}$-file terhadap kemampuan simulasi GUI pada program MATLAB.Setelah melakukan uji regresi linier sederhana dilakukan uji signifikansi dengan uji $F$ untuk menentukan apakah hipotesis yang di ajukan di terima atau di tolak.

Hasil perhitungan uji regresi linier sederhana menggunakan Minitab diperoleh simulasi GUI $(Y)=35.0+0.527$ simulasi $M$-file $(X)$. Makna dari persamaan regresi tersebut adalah apabila simulasi M-file ditingkatkan sebesar satu satuan persen maka simulasi pada GUI akan bertambah sebesar 0.527 dari faktor lain yang tidak diamati.

Hasil perhitungan analisis regresi linier sederhana simulasi GUI $(Y)=35.0+0.527$ simulasi $\mathrm{M}$-file $(\mathrm{X})$ juga memperlihatkan taksiran parameter $\mathrm{b}=0.527$ berharga positif yang artinya bahwa simulasi M-file terdapat pengaruh positif terhadap kemampuan simulai GUI.

Hasil perhitungan diperoleh nilai $r_{\text {hitung }}$ product moment menggunakan MINITAB = 0,611 . Nilai ini selanjutnya dibandingkan dengan nilai $r_{\text {tabel }}$ dengan taraf signifikan $5 \%$ dan diperoleh nilai $r_{\text {tabel }}=0,325$. Hal tersebut, diperoleh bahwa $r_{\text {hitung }}>r_{\text {tabel }}$ sehingga dari hasil ini menunjukkan ada hubungan antara Simulasi M-File Terhadap Kemampuan Membuat Simulasi Berbasis GUI pada program MATLAB

Penelitian ini mengukur kemampuan membuat simulasi berbasis M-file dan kemampuan membuat simulasi berbasis GUI dibagi menjadi tiga kriteria yaitu tinggi, sedang dan rendah. Dari hasil kemampuan membuat simulasi berbasis M-File terdapat 10 orang mahasiswa yang kemampuan membuat simulasi M-file dengan presentase sebesar $27 \%$, 27 orang mahasiswa memiliki kemampuan berbasis M-file dalam kategori sedang dengan presentase sebesar $73 \%$ dan tidak ada mahasiswa yang memiliki kemampuan simulasi Mfile dalam kategori rendah dan hasil kemampuan membuat simulasi berbasis GUI (Grafical User Interface) terdapat 8 orang mahasiswa memiliki Hasil kemampuan berbasis GUI dalam kategori tinggi dengan presentase sebesar $22 \%, 29$ orang mahasiswa memiliki Hasil kemampuan berbasis GUI dalam kategori sedang dengan presentase sebesar $78 \%$ dan tidak ada mahasiswa yang memiliki kemampuan simulasi GUI dalam kategori rendah.

\section{SIMPULAN}

Kesimpulan dari hasil analisis data dan pembahasan dalam penelitian ini, maka dapat disimpulkan" Ada Pengaruh Kemampuan Mahasiswa Membuat Simulasi Berbasis M-File Terhadap Kemampuan Membuat Simulasi Berbasis GUI (Grafical User Interface) Pada 
Program MATLAB". Hal ini dibuktikan Karena $F_{\text {hitung }}>F_{\text {tabel }}$ atau $20.804,10$ maka hipotesis diterima. Sehingga berdasarkan kriteria pengujian hipotesis yaitu: Jika $F_{\text {hitung }}>F_{\text {tabel, }}$ maka dikatakan signifikan (Hipotesis diterima).

\section{DAFTAR PUSTAKA}

Arifin, Z. (2012). Penelitian Pendidikan Metode dan Paradigma Baru. Bandung: Rosdakarya. Hakim, M. I., \& Zulkifli, M. (2021). Analysis of the problems of Islamic education teachers in the assessment of student's critical thinking ability. UNNES-TEFLIN National Seminar, 4(1), 337-345. Retrieved from http://utns.proceedings.id/index.php/utns/article/view/125

Pusadan. M.Y. (2012). Pemograman Matlab Pada Sistem Pakar Puzzy. Yoyakarta: CD BUDI UTAMA.

Ramayulis. (2011). IImu Pendidikan Islam. Jakarta: Kalam Mulia.

Richard, I. L., David. S. R., Joel. P. S., Everette. S. Gardner. (2002). Pengambilan Keputusan Secara Kuantitatif. Jakarta: PT Raja Grafindo Persada.

Sugiharto. A. (2006). Pemograman Gui Dengan Matlab. Yoyakarta: ANDI OFFSET.

Sugiyono. (2013). Statistika Untuk Penelitian. Bandung: Alfabeta.

Sugiyono. (1014). Metode Penelitian Pendidikan Pendekatan Kuantitatif Kualitatif Dan R \& D. Bandung: Alfabeta.

Suharsimi. A. (2006). Prosedur Penelitian Suatu Pendekatan Praktik. Jakarta: Rineka Cipta. (2002). prosedur pendekatan praktik. Jakarta: Rineka Cipta.

Zulkifli, M. (2020). Quantitative Data Analysis "Effectiveness Of The Graphomotor Method On The Ability To Write Students". Al-Mujahidah: Jurnal Pendidikan Guru Madrasah Ibtidaiyah, 1(2): 104-117. https://doi.org/10.51806/al-mujahidah.v1i2.15 